\title{
HUBUNGAN EKSPRESI Ki-67 DENGAN KARAKTERISTIK HISTOPATOLOGIK PADA KANKER PAYUDARA TRIPEL NEGATIF
}

\author{
Aswiyanti Asri ${ }^{1}$, Pamelia Mayorita ${ }^{1}$, Daan Khambri ${ }^{2}$
}

\begin{abstract}
Abstrak
Kanker payudara triple negative mempunyai prognosis paling buruk. Ki-67, derajat diferensiasi dan invasi limfovaskular (LVI) adalah parameter prognostik patomolekuler, dimana Ki-67 juga dipakai sebagai prediktor respon terapi. Penelitian ini bertujuan untuk mengetahui hubungan derajat diferensiasi dan LVI dengan ekspresi Ki-67 pada kanker payudara tripel negatif. Sembilan belas kasus kanker payudara tripel negatif dikumpulkan dan direview ulang derajat diferensiasi dan LVI. Hasil pemeriksaan Ki-67 dikelompokkan dimana $\leq 10 \%$ sampai $29 \%$ ekspresi rendah-sedang; dan $>30 \%$ ekspresi tinggi. Hubungan antara ekspresi Ki-67 dengan derajat diferensiasi dan invasi limfovaskular dianalisis menggunakan Chi Square. Dari 19 kasus kanker payudara tripel negatif, 52,6 \% kasus mempunyai derajat diferensiasi tinggi dan sisanya derajat diferensiasi rendah. Invasi limfovaskular ditemukan positif pada 68,4\% kasus. Ekspresi Ki-67 yang tinggi hanya ditemukan pada 1 kasus. Uji statistik antara ekspresi Ki-67 dengan derajat diferensiasi maupun dengan invasi limfovaskular tidak ditemukan hubungan yang bermakna. Tidak ditemukan korelasi antara ekspresi Ki-67 dengan derajat diferensiasi dan invasi limfovaskular pada kanker payudara tripel negatif.
\end{abstract}

Kata Kunci: kanker payudara triple negative, Ki-67, derajat diferensiasi, LVI

\begin{abstract}
Triple negative breast cancer is one of the breast cancer with poorest prognosis. Ki- 67 , grade and lymphovascular invasion are the prognostic pathomolecular parameter, and also used as a predictor of response to therapy. The objective of this study was to identify the relationship between Ki-67 expression with grade and lymphovascular invasion in triple negative breast cancer. We found 19 cases of triple negative breast cancer, and performed slide review for grade and lymphovascular invasion. The results of Ki-67 expression were classifiy as low intermediate (<10\% - 29\%) and high (>30\%). We use Chi Square test to assest the relationship between variables. Of 19 triple negative breast cancer cases, 52,6\% of cases were found to have high histopathological grade. Positive lymphovascular invasion was seen in $68,4 \%$ cases. Only one case was found with high expression of Ki-67. There were no correlation between Ki-67 expression with histopathological grade and lymphovascular invasion on triple negative breast cancer. There were no significant relationship between Ki-67 expression with grade and lymphovascular invasion on triple negative breast cancer.
\end{abstract}

Keywords : triple negative brest cancer, Ki-67, differentiation grade, LVI

Afiliasi penulis : 1 . Bagian Patologi Anatomi Fakultas Kedokteran Unand/RSUP Dr. M. DJamil Padang, 2. Bagian Bedah Fakultas Kedokteran Universitas Andalas/RSUP Dr.M.DJamil Padang. Korespondensi: Aswiyanti Asri Bagian Patologi Anatomi Fakultas Kedokteran Universitas Andalas, Jl. Perintis Kemerdekaan No. 94 PO BOX. 49 Padang 25127. Email : Aswiyanti.Asri@gmail.com, HP : 081264801469. 


\section{PENDAHULUAN}

Kanker payudara adalah tumor ganas yang berasal dari epitel kelenjar payudara. Kanker ini menduduki peringkat pertama keganasan tersering pada wanita di Amerika Utara, Eropa Barat Selatan dan Australia. Di Amerika Serikat, sekitar 100.000 kasus baru didiagnosis setiap tahunnya dan sekitar 30.000 pasien meninggal akibat penyakit ini. $^{1}$

Berdasarkan data dari Badan Registrasi Kanker Perhimpunan Dokter Spesialis Patologi Indonesia pada tahun 2006 kanker payudara di Indonesia menempati peringkat kedua tumor ganas terbanyak pada wanita setelah kanker leher rahim. Kasus ini mengalami peningkatan pada tahun 2009 menjadi peringkat pertama yaitu sebanyak 4.130 $(18,19 \%)$ kasus. $^{2,3}$ Kanker payudara menempati urutan pertama di Sumatera Barat, dengan jumlah kasus yang semakin meningkat setiap tahun. ${ }^{2,3}$

Kanker payudara merupakan penyebab kematian terbanyak akibat kanker pada wanita berusia 35-55 tahun. Penyakit ini bersifat heterogen baik secara klinis maupun patologik sehingga sulit untuk memperkirakan masa kelangsungan hidup karena derajat keganasan sangat bervariasi, demikian juga respon pasien terhadap pengobatan. Angka kelangsungan hidup 5 tahun diperkirakan sekitar 65\%, dengan perbedaan yang besar pada setiap stadium. ${ }^{4,5}$

Berbagai penelitian telah dilakukan untuk mencari parameter prognosis pada kanker payudara, baik secara klinik, patologik maupun molekuler. Beberapa parameter prognosis yang dikenal antara lain usia penderita, ukuran tumor, status kelenjar getah bening, derajat diferensiasi histologik, subtipe histologik, invasi vascular dan status estrogen reseptor. ${ }^{5}$ Klasifikasi WHO terbaru (2012), subtipe yang dikenal antara lain invasive carcinoma of no special type (dulu dikenal sebagai invasive ductal carcinoma), invasive lobular carcinoma, medullary carcinoma dan sebagainya ${ }^{6}$.

Penelitian terdahulu didapatkan bahwa kanker payudara dengan parameter histologi yang sama dapat menunjukkan profil biomolekuler yang berbeda ${ }^{7}$. Oleh karena itu disusunlah klasifikasi molekular karsinoma payudara berdasarkan status estrogen reseptor, progesteron reseptor, ekspresi Her2/neu dan Ki-67, yang terdiri atas luminal A, luminal B, Her-2 positif dan tripel negatif. Luminal A mempunyai prognosis paling baik dan tripel negatif adalah subtipe dengan prognosis paling buruk. $^{8,9}$ Kanker payudara tripel negatif dibandingkan dengan tipe lainnya bersifat agresif karena tumbuh lebih cepat, lebih tinggi kemungkinan untuk bermetastasis dan sering rekurens. Disamping itu belum ada target terapi untuk kanker payudara tipe ini karena sel tumor tidak mempunyai reseptor untuk target terapi tersebut. ${ }^{10}$

Derajat diferensiasi adalah salah satu parameter prognosis yang sudah dikenal luas pemanfaatannya. Penilaian derajat diferensiasi yang sudah diterima luas pada kanker payudara adalah sistem berdasarkan kriteria kombinasi Nottingham (modifikasiElston-Ellis dari system penderajatan Scarff-BloomRichardson), yang terdiri atas pembentukan struktur tubulus, pleomorfisme inti 
dan jumlah mitosis. Derajat diferensiasi dikelompokkan kedalam tiga kategori yaitu derajat diferensiasi baik (derajat 1), derajat diferensiasi sedang (derajat 2) dan derajat diferensiasi buruk (derajat 3). Makin buruk derajat diferensiasi, menunjukkan sel tumor mempunyai kemampuan yang semakin berbeda dengan sel asal dan tumbuh lebih cepat. ${ }^{6,7}$

Invasi vaskular didefinisikan sebagai penetrasi sel-sel tumor ke dalam lumen arteri atau vena. Penilaian parameter ini penting terutama pada pasien dengan metastasis ke kelenjar getah bening negatif, kaena dapat memperkirakan risiko metastasis ke kelenjar limfe. Invasi vaskular ditemukan pada 5 - 50\% kasus kanker payudara.,

Dalam keadaan normal atau homeostasis maka pertumbuhan jaringan ditentukan oleh kecepatan proliferasi, diferensiasi dan apoptosis. Apabila tubuh mengalami gangguan seperti kanker maka kecepatan proliferasi, dan diferensiasi akan menjadi meningkat. Proliferasi sel adalah pembelahan sel (cell division) dan pertumbuhan sel (cell growth), yang diatur oleh siklus sel. Dalam keadaan normal siklus sel akan terkontrol dengan baik tetapi pada tumor atau keganasan, siklus sel akan mengalami disregulasi aktivitas siklin dan CDK (Cycline Dependent Kinase) sehingga memudahkan sel untuk berproliferasi. Aktivitas proliferasi sel dapat dideteksi dengan menggunakan imunohistokimia $\mathrm{Ki}-67$ yang akan mengekspresikan tiap fase pada siklus sel. ${ }^{11}$ Berdasarkan ekspresi Ki-67, rekomendasi St.Gallen Consencus Conference menyatakan bahwa ekspresi ini dibagi menjadi ekspresi rendah/low dan ekspresi tinggi/high.
Tingkat proliferasi ini digunakan sebagai indikator untuk pemberian terapi ajuvan. $^{12}$

Berdasarkan uraian diatas maka penulis tertarik untuk meneliti bagaimana relevansi karakteristik histopatologik (diferensiasi dan invasi limfovaskular) dengan penanda proliferasi sel Ki-67 pada kanker payudara tripel negatif.

\section{METODE}

Sebanyak 19 kasus karsinoma payudara invasif yang sudah diketahui termasuk tipe tripel negatif dari hasil pemeriksaan ER, PR, Her-2/neu, yang dirawat di bagian Bedah RSUP Dr. M.Jamil Padang pada periode dikumpulkan dari 1 Januari 2010 sampai 31 Desember 2013. Ekspresi Ki-67 juga sudah dilakukan pemeriksaan bersamaan dengan pemeriksaan ER, PR, Her2/neu. Ekspresi Ki-67 yang didapat kemudian dikelompokkan kedalam ekspresi rendah dan tinggi berdasarkan rekomendasi St. Gallen 2015 dimana $\leq 10 \%$ sampai $29 \%$ ekspresi rendah sedang ; dan $>30 \%$ ekspresi tinggi.

Blok parafin dan slide kanker payudara dikumpulkan kembali kemudian dilakukan review untuk mendapatkan data derajat diferensiasi dan invasi limfovaskular. Karakteristik histopatologik yang dinilai adalah derajat diferensiasi dan invasi limfovaskular. Derajat diferensiasi ditentukan berdasarkan kriteria kombinasi Nottingham, terdiri atas derajat 1,2 dan 3, kemudian dikelompokkan lagi menjadi derajat rendah (derajat 1-2) dan tinggi (derajat 3). Invasi limfovaskular (LVI) dinilai berdasarkan ada/tidaknya sel tumor di 
dinding dan/atau lumen vaskular (positif/negatif).

\section{HASIL DAN PEMBAHASAN}

Penelitian dilakukan secara retrospektif terhadap kasus kanker payudara subtipe molekular tripel negatif yang dirawat di bagian Bedah RSUP. Dr. M. Djamil Padang dari 1 Januari 2010 sampai 31 Desember 2013. Selama periode tersebut didapatkan 19 kasus kanker payudara tripel negatif dari 66 kasus kanker payudara (28\%) , yang juga dilakukan pemeriksaan Ki-67. Distribusi derajat diferensiasi invasi limfovascular dan ekspresi Ki-67 kanker payudara tripel negatif dapat didilihat pada tabel 1.

Tabel 1. Distribusi Derajat Diferensiasi, Invasi Limfovaskular dan Ekspresi Ki-67 Kanker Payudara Tripel Negatif

\begin{tabular}{|c|c|}
\hline Karakteristik & Frekuensi (\%) \\
\hline \multicolumn{2}{|l|}{ Derajat diferensiasi } \\
\hline Derajat rendah & $9(47,4)$ \\
\hline Derajat tinggi & $10(52,6)$ \\
\hline \multicolumn{2}{|l|}{ LVI } \\
\hline Positif & $13(68,4)$ \\
\hline Negatif & $6(31,6)$ \\
\hline \multicolumn{2}{|l|}{ Ekspresi Ki-67 } \\
\hline Ekspresi rendah-sedang & $18(94,7)$ \\
\hline Ekspresi tinggi & $1(5,3)$ \\
\hline
\end{tabular}

Tabel 1 dapat dilihat bahwa kanker payudara tripel negatif paling banyak ditemukan pada derajat diferensiasi tinggi yaitu sebanyak 10 $(52,6 \%)$ dan LVI $(68,4 \%)$, tetapi ekspresi
Ki-67 tinggi hanya ditemukan pada 1 kasus $(5,3 \%)$.

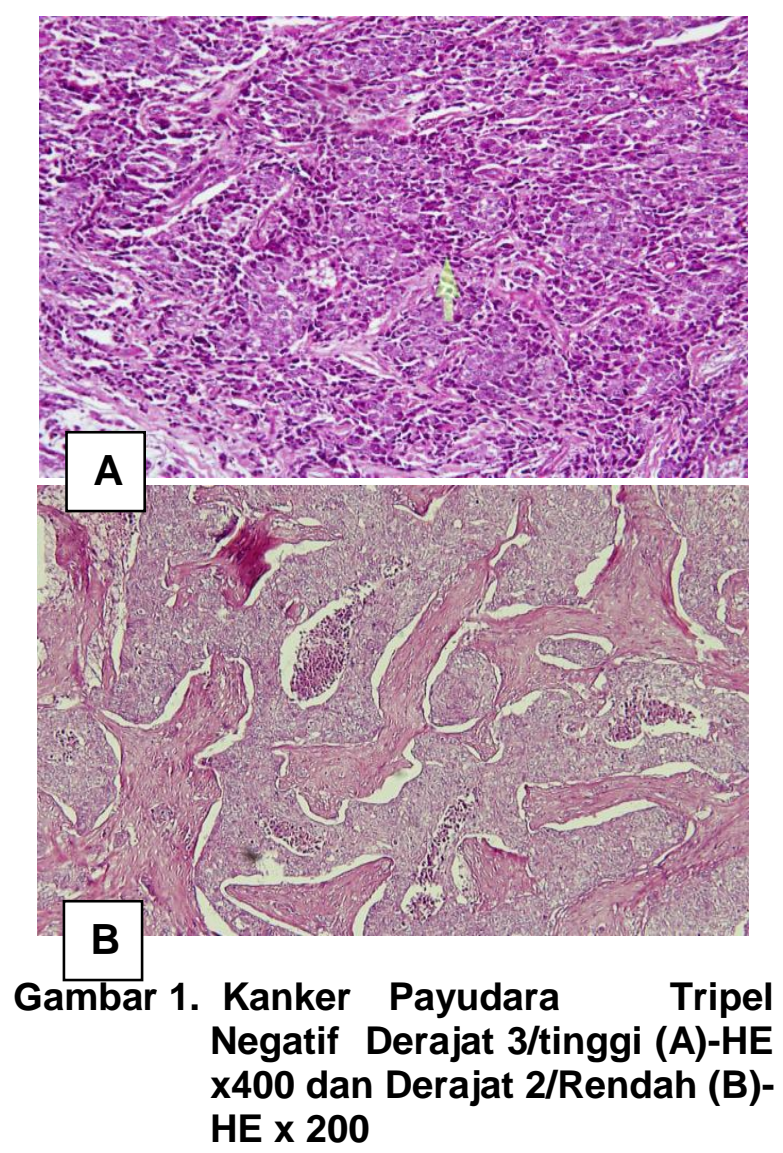

Gambar 1 menunjukkan bahwa gambaran mikroskopik kanker payudara dengan derajat diferensiasi 3/tinggi (A) dan $2 /$ rendah (B), sedangkan gambar 2 menunjukkan kanker payudara dengan LVI positif.

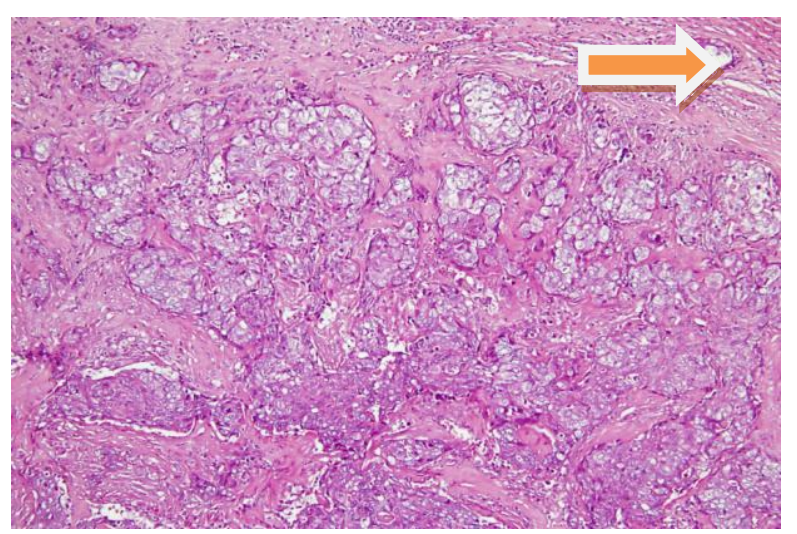

Gambar 2. Kanker Payudara Tripel Negatif dengan LVI Positif HEx200. 
Hubungan ekspresi Ki-67 dengan derajat diferensias dapat ditemukan pada tabel 2. Pada tabel 2 terlihat bahwa ekspresi Ki-67 yang tinggi didapatkan pada 1 kasus kanker payudara tripel negatif dengan derajat diferensiasi tinggi. Analisis statistik tidak menunjukkan hubungan yang bermakna antara ekspresi Ki-67 dengan derajat diferensiasi.

Tabel 2. Hubungan Ekspresi Ki-67 dengan Derajat Diferensiasi

\begin{tabular}{lccc}
\hline \multicolumn{1}{c}{$\begin{array}{c}\text { Ekspresi } \\
\text { Ki-67 }\end{array}$} & \multicolumn{2}{c}{$\begin{array}{c}\text { Derajat } \\
\text { Diferensiasi }\end{array}$} & $\begin{array}{c}\boldsymbol{p} \text { - } \\
\text { value }\end{array}$ \\
\cline { 2 - 3 } & $\begin{array}{c}\text { Derajat } \\
\text { Rendah }\end{array}$ & $\begin{array}{c}\text { Derajat } \\
\text { Tinggi }\end{array}$ & \\
\hline Ekspresi & 9 & 9 & \\
Rendah Sedang & & & 0,053 \\
Ekspresi Tinggi & 0 & 1 & \\
\hline
\end{tabular}

Tabel 3. $\begin{gathered}\text { Hubungan } \\ \text { dengan LVI }\end{gathered}$ Ekspresi Ki-67

\begin{tabular}{lccc}
\hline \multirow{2}{*}{ Ekspresi Ki-67 } & \multicolumn{2}{c}{ LVI } & $\begin{array}{c}\boldsymbol{p} \text { - } \\
\text { value }\end{array}$ \\
\cline { 2 - 3 } & Positif & Negatif & \\
\hline Ekspresi & 12 & 6 & \\
Rendah- Sedang & & & 2,579 \\
Ekspresi Tinggi & 1 & 0 & \\
\hline
\end{tabular}

Dari tabel 3 terlihat bahwa ekspresi Ki-67 yang tinggi didapatkan pada 1 kasus kanker payudara tripel negatif dengan LVI positif. Analisis statistik tidak menunjukkan hubungan yang bermakna antara ekspresi $\mathrm{Ki}-67$ dengan LVI.

Selama periode 1 Januari 2010 sampai 31 Desember 2013 ditemukan 66 kasus kanker payudara di bagian Bedah RSUP. Dr. M. Djamil Padang, dimana 19 kasus (28\%) adalah subtipe molekuler tripel negatif. Angka ini tidak berbeda jauh dengan kasus di FKUI/RSCM yaitu sebesar $30 \%$ tetapi lebih tinggi dibanding angka yang didapat Su et al (2011) di Cina yaitu $12,9 \%$ kasus. Kanker payudara di Indonesia menduduki peringkat kedua setelah kanker serviks tetapi peringkat pertama di Sumatera Barat. Lebih dari $50 \%$ pasien kanker payudara di Indonesia datang pada stadium lanjut, dengan ketahanan hidup yang juga rendah. 2,3,13,14 Apabila dilihat dari subtipe molekular dimana angka tripel negatif cukup besar maka hal ini kemungkinan menjadi salah satu penyebab survival rate yang rendah. Perlu dilakukan penelitian lebih lanjut mengenai faktor penyebab survival rate yang rendah ini serta faktor predisposisi kejadian kanker payudara tripel negatif pada wanita Indonesia. Boyle P ( 2012) dalam penelitiannya menemukan bahwa kanker payudara tripel negatif lebih banyak ditemukan pada wanita kulit hitam, usia muda dan obese. $^{15}$

Tabel 1 menunjukkan bahwa derajat diferensiasi tinggi (derajat 3) dan LVI positif lebih banyak ditemukan pada kanker payudara tripel negatif (52,6\% dan $68,4 \%$ ). Hal ini sesuai dengan penelitian Kosasih et al (2011) di RS Sanglah, Bali yang menemukan 59,1\% kanker payudara derajat tinggi. Demikian juga sesuai dengan penelitian oleh Rahniayu et al (2011) di RSUD Dr. Soetomo Surabaya yang menemukan mayoritas (64,7\%) kanker payudara tripel negatif dengan derajat diferensiasi tinggi/3. Derajat diferensiasi yang lebih tinggi berhubungan dengan sifat tumor yang lebih agresif dan prognosis yang 
lebih buruk. Makin tinggi derajat diferensiasi dihubungkan dengan tingkat proliferasi yang lebih tinggi pula. Invasi limfovaskular (LVI) adalah tahap yang sangat penting dalam proses metastasis. Pada konferensi St. Gallen 2005, LVI dimasukkan sebagai faktor prognostik pada kanker payudara tanpa metastasis ke kelenjar getah bening (KGB), dimana mortalitas pasien kanker payudara tanpa metastasis KGB namun dengan LVI (+) lebih tinggi dibanding dengan LVI (-). LVI juga berhubungan dengan faktor prognostik lainnya seperti ukuran tumor dan derajat diferensiasi. Pada penelitian ini ditemukan 68,4\% kasus dengan LVI (+). Dari kepustakaan juga disebutkan bahwa kanker payudara tripel negatif memiliki gambaran klinis dan patologik yang lebih agresif dibanding subtipe molekular lainnya, walaupun lebih respon terhadap kemoterapi. Hal ini disebabkan pendeknya waktu disease free survival dan lebih besar kemungkinan bermetastasis. ${ }^{16,17,18,19}$

Ki-67 adalah protein yang diekspresikan dalam inti sel selama siklus sel. Makin tinggi ekspresi Ki-67, berarti semakin banyak sel (tumor) yang berproliferasi. Oleh karena itu Ki-67 sekarang banyak dipakai sebagai penanda aktivitas proliferasi. Ekspresi Ki-67 digunakan sebagai prediktor untuk respons terapi hormonal dan kemoterapi. Beberapa peneliti menemukan korelasi antara ekspresi Ki-67 dengan waktu disease free- survival dan survival rates serta risiko rekurensi yang lebih tinggi pada tumor dengan ekspresi Ki-67 tinggi. Berbagai metode digunakan untuk menilai ekspresi Ki-67 antara lain imunohistokimia, PCR, tissue micro array ${ }^{20,21}$. Berbagai cara juga diapli- kasikan untuk menentukan cut of point dan standarisasi penilaian ekspresi Ki-67 dengan menggunakan metode imunohistokimia, antara lain Allred scoring $^{22}$. Dalam konferensi St. Gallen 2015 ditetapkan cut of point untuk kanker payudara yaitu $\leq 10 \%$ sampai 29 $\%$ ekspresi rendah - sedang ; dan $>30 \%$ ekspresi tinggi ${ }^{12}$. Widodo et al (2013) menemukan hubungan yang bermakna antara limfangiogenesis dengan ukuran tumor, derajat diferensiasi, status KGB, LVI, ekspresi p53 dan Ki-67 ${ }^{23}$.

Dari tabel 2 dan 3 terlihat bahwa ekspresi Ki-67 yang tinggi didapatkan pada 1 kasus kanker payudara tripel negatif dengan derajat diferensiasi tinggi dan LVI positif. Analisis statistik tidak menunjukkan hubungan yang bermakna antara ekspresi Ki-67 dengan derajat diferensiasi dan antara ekspresi Ki-67 dengan LVI. Hasil ini berbeda dengan yang ditemukan peneliti lain dimana ekspresi Ki-67 tinggi ditemukan pada 74,6 $\%$ kasus kanker payudara ${ }^{24}$. Banyak faktor teknis yang dapat mempengaruhi hasil pewarnaan dan penilaian Ki-67 dengan metode imunohistokimia. Menurut rekomendasi Breast Cancer Working Group, sampel jaringan yang digunakan dapat berasal dari core biopsy maupun tumor keseluruhan, harus difiksasi dengan buffer formalin, disertai kontrol positif dan kontrol negatif dalam pewarnaannya, menggunakan microwave untuk antigen retrieval, menggunakan antibodi yang disarankan yaitu MIB1, yang dinilai positif adalah nuclear staining dan penilaian dilakukan setidaknya pada 500 sel tumor yang invasif ${ }^{25}$. Pewarnaan imunohistokimia juga sangat ditentukan oleh prosesing jaringan saat membuat blok parafin. Walaupun sudah direko- 
mendasikan, tetapi masih banyak RS yang belum menggunakan buffer formalin sebagai larutan fiksatif. Selain itu belum banyak laboratorium Patologi Anatomi yang sudah terstandarisasi dan melakukan Quality Assurance sehingga hasil pemeriksaan, khususnya imunohistokimia juga berbeda-beda.

\section{SIMPULAN}

Ekspresi Ki-67yang tinggi hanya ditemukan pada 1 kasus, sedangkan derajat diferensiasi tertinggi (derajat 3) dan LVI yang positif lebih banyak ditemukan pada kanker payudara tripel negatif. Hal ini menunjukkan bahwa secara histopatologik, kanker payudara tripel negatif

\section{DAFTAR RUJUKAN}

1. Rosai J. Breast. In surgical pathology. $9^{\text {th }}$ ed. Edinburgh: Mosby ; 2004.

2. Badan Registrasi Kanker IAPI, Data histopatologik, Direktorat Jenderal Pelayanan Medik Departemen Kesehatan RI, Badan Registrasi Kanker Perhimpunan Dokter Spesialis Patologi Indonesia. Jakarta Yayasan Kanker Indonesia; 2006.

3. Badan Registrasi Kanker IAPI, Data histopatologik, Direktorat Jenderal Pelayanan Medik Departemen Kesehatan RI, Badan Registrasi Kanker Perhimpunan Dokter Spesialis Patologi Indonesia. Jakarta. Yayasan Kanker Indonesia; 2009.

4. Rosen PP. Rosen's Breast Pathology. $3^{\text {rd }}$ ed. Philadelphia. Lippincott William and Wilkins; 2009.

5. Uzzan, B, Nicolas $P$, Cucherat M, Perret GY. Microvessel density as a prognostic factor in women with breast cancer, in A Systematic Review of the Literature and lebih progresif. Perlu dipertimbangkan permasalahan teknis dalam pewarnaan dan penilaian ekspresi Ki-67. Tidak ditemukan hubungan yang bermakna antara ekspresi Ki-67 dengan derajat diferensiasi dan invasi limfovaskular pada kanker payudara tripel negatif. Disarankan untuk dilakukan penelitian lanjutan dengan jumlah sampel yang lebih besar, penilaian ekspresi Ki-67 yang terstandarisasi dan dihubungkan dengan ketahanan hidup penderita.

Meta-Analysis. Am J Cancer 2004;193140.

6. Colditz G, Chia KS. WHO classification of tumours of the breast: invasive breast carcinoma, IARC. $4^{\text {th }}$ ed. Lyon; 2012.

7. Lester SC. The Breast. In Pathologic Basis of Disease. Editor Robbins and Cotran. 9th ed. Philadelphia: Elsevier Saunders; 2015:1043 - 72.

8. Cheang. Determination of breast cancer subtypes. In St. Gallen. International Breast Cancer Conference;2011.

9. Shomaf M, Masad J, Najjar S, Faydi D. Distribution of breast cancer subtypes among Jordanian women and correlation with histopatholgical grade: Molecular subclassification study. JRSM Short Rep 2013; 4(10) :204-53.

10. Chen J-Q, Russo J. ER- $\alpha$ negative and triple negative breast cancer : molecular features and potential theraupetic approaches. NIH Public Access. Bioch Biophys Acta 2009; 1796(2):162-75. 
11. Kumar, Abbas, Aster . Neoplasia In : Pathologic Basis of Disease. Robbins and Cotran editor. $9^{\text {th }}$ ed. Philadelphia Elsevier Saunders 2015:265-340.

12. Esposito A, Cristiciello C, Curigliano G. Conference report: Highlights from the $14^{\text {th }}$ St.Gallen International Breast Cancer Conference in Vienna: dealing with classification, prognosti-fication, and prediction refinement to personalize the treatment of patients with early breast cancer. Cancer Med Sci 2015; 9:518.

13. Hardjolukito ESR. Triple negative breast cancer. In Symposium and Workshop: Recent Adv Patholog, Jakarta; 2010.

14. Su Y, Zheng Y, Zheng W, Gu K, Chen Z, $\mathrm{Li} G$, et al. Distinct distribution and prognosis significance of molecular subtypes of breast cancer in Chinese women: a population-based cohort study. 2011. Available from: http://www.biomed central.com/1471-2407/11/292.

15. Boyle P. Triple-negative breast cancer: epidemiological considera-tions a recommendations. Annals Onco 2012;23.

16. Kosasih J, Artha GA. Hubungan overekspresi topoisomerase II alfa dengan overekspresi Her-2/neu dan berbagai derajat histologik karsinoma duktal invasif tidak spesifik payudara. Majalah Patologi Indonesia 2011; 20(1):6-13.

17. Rahniayu A, Susilo I. Ekspresi epidermal growth factor receptor pada karsinoma duktal invasif payudara triple negative, hubungan dengan ekspresi Ki67, besar tumor dan derajat histologik. Majalah Patologi Indonesia 2011;20(2):16-21.

18. Ismail-Khan R, Bui MM. A review of triple negative breat cancer. Cancer Control 2010;17(3):173-76.

19. Mohammed ZMA, McMillan DC, Edwards J, Mallon E, Doughty JC, Orange $\mathrm{C}$, et al. The relationship between lymphovascular invasion and angiogenesis, hormone receptors, cell proliferation and survival in patients with primary operable invasive ductal breast cancer. BMC Clin Pathol 2013;13 (31).

20. Beresford M, Wilson GD, Makris A. Measuring proliferation in breast cancer: practicalities and applica-tions. Breast Cancer Research 2006 ;8:216.

21. Result from the NordiQC Ki 67 Web module:Breast cancer module 2013.

22. Allred DC. Scoring immunostained slides. Modern Pathol 1998 ; 11(2) : 155-168.

23. Widodo I, Ferronika $P$, Harijadi A, Triningsih FXE, Utoro $T$, Soeripto. Clinicopathological significance of lymphoangiogenesis and tumor lymphovascular invasion in Indonesian breast cancers. Asian Pacific J Cancer Prev 2013;14:997- 1001.

24. Ermiah E, Buhmeida A, Abdalla F, Khaled BR, Salem N, Pyrhonen S, et al. Prognostic value of proliferation marker : immunohistochemical Ki-67 expression and cytometric S-phase fraction of women with breast cancer in Libya. $\mathrm{J}$ Cancer 2012;3:421-31.

25. Dowsett $M$, Nielsen TO, A'Hern R, Bartlett J, Coombes RC, Cuzick J, et al. Assessment of Ki67 in breast cancer: recommendations from the International Ki67 in breast cancer working group. JNCI 2011;103(22): 1656-64. 